\title{
Catheter meaning for the adolescents in dialysis
}

\author{
Liliana Cristina Morales, Mg ${ }^{1}$, Edelmira Castillo, PhD²
}

\section{SUMMARY}

Goal: Terminal renal failure affects all the person's life dimensions. The impact of this illness during adolescence is quite dramatic because the adolescent must live with the illness demands and the demands from this crucial developmental stage. Knowledge regarding the impact of the dialysis catheter on the adolescent's life is spare.

Methodology: A phenomenological study was carried out with 8 female and male adolescents that were in dialysis.

Findings: The adolescents had to learn to live with the dialysis catheter in their body. The catheter became an obstacle to achieve their identity and deteriorated their physical appearance and peer relationships.

Keywords: Adolescents; Dialysis catheter; Chronic illness.

Significado del catéter para los(as) adolescentes en diálisis

\section{RESUMEN}

Objetivo: La insuficiencia renal terminal afecta todas las dimensiones de la vida de las personas. El impacto de esta enfermedad durante la adolescencia es más dramático debido a que el(a) adolescente debe además de superar las demandas de esta etapa de la vida, vivir según las demandas de la enfermedad. El conocimiento sobre el impacto del catéter para la diálisis en la vida de los (as) adolescente es escaso.

Metodología: Se realizó un estudio fenomenológico con 8 jóvenes de ambos sexos que estaban en diálisis.

Resultados: Los(as) jóvenes tuvieron que aprender a vivir con el catéter en su cuerpo. El catéter les generó deterioro de la apariencia física y de las relaciones con los pares, además se constituyó en un obstáculo para lograr la identidad.

Palabras clave: Adolescentes; Catéter de diálisis; Enfermedad crónica.

The adolescence is the stage of the vital cycle with the lowest morbidity and mortality ${ }^{1}$. However, in the last 10 years, there has been an increase of chronic diseases in adolescents from $5 \%$ to $31 \%^{2}$; chronic renal failure (CRF) is one of these diseases. CRF is a worldwide public health problem with increasing incidence and prevalence, poor prognosis and a high cost ${ }^{3}$. In United States, the incidence for children (0-19 years) is 11/ million/persons/year ${ }^{3}$. InColombia, theaverage incidence is 3-6 million/persons/year ${ }^{4}$. In Cali and Valle del Cauca, there is about 1,000 persons in dialysis therapy that represent $15 \%$ of the Colombian patients; 250 of these are children ${ }^{5}$.

CRF has a great impact on the adolescents' life. The adolescents must cope simultaneously with the challenges from adolescence and the illness. On one hand, they are living in a permanent stage of ambivalence, contradictions, and search; they are concerned by and frequently unhappy with their physical appearance due to the physiologic and morphologic changes they are going thru; they struggle for their independence and continuously seek for identity. On the other hand, they face a chronic illness that has additional challenges and great stress.

The adolescents with CRF have problems related to body image and isolation that affect their development and their opportunities to achieve goals, independence, and meaningful interpersonal relationships ${ }^{6}$. The lived experiences of adolescents with CRF in dialysis have not been studied as such; most of the studies of adolescents with chronic illness have been done with adolescents suffering from other diseases such as diabetes, AIDS,

1. Assistant Professor, Nursing School, Universidad del Valle, Cali, Colombia. e-mail: lilicmv@univalle.edu.co

2. Professor, Nursing School, Universidad del Valle, Cali, Colombia. e-mail: edelcases59@yahoo.com

Received for publication August 9, 2007 Accepted for publication July 1, 2009 
cancer, cystic fibrosis and using methodologies that do not allow the description of the adolescent's everyday concerns, care practices, habits and difficulties from their own perspective.

The published studies regarding the dialysis catheter are quantitative and focus on clinical issues such as: infection incidence ${ }^{7,8}$ and dialysis effectiveness according to the catheter diameter and insertion technique ${ }^{9-14}$. There is scarcity of studies regarding the psychological impact of the dialysis catheter on the adolescent suffering CRF.

This study was done to describe the adolescent's lived experiences with the illness and the treatment, as a contribution to the scientific knowledge about the life of the adolescent with CRF. The knowledge derived from this study should help nurses and other health professionals in providing care that is based on the adolescent's lived world, which could help the teenagers in adapting to the illness situation with the less possible suffering for them and their families. This paper only describes the findings regarding the meaning of the dialysis catheter for the adolescents in their everyday life.

\section{METHODOLOGY}

Design. The methodological strategy used to carry out the study was the interpretive phenomenology based on Heidegger ontological philosophy. The goal of this phenomenology is to understand the everyday experiences and to articulate similarities and differences in meanings, concerns, practices, skills, and experiences of human beings ${ }^{15,16}$. Therefore, it is a methodology appropriate to study the lived experiences of the adolescent suffering from CRF and having dialysis.

Sample. The study participants met the following criteria: 10-18 years of age, being active in peritoneal dialysis or hemodialysis. To be active in peritoneal dialysis, the adolescent should have the daily dialysis according to the Renal Unit Protocols; to be active in hemodialysis, the adolescent should come to the Renal Unit four times a week for dialysis. The sample was comprised by eight participants: four women and four men; women age was 13-16 years and men age 14-17 years; six participants were in high school and two had finished high school; during the study, two participants abandoned their school.
Data collection and analysis. Before collecting data, one of the researchers contacted the adolescents and their parents during two months. During this time, the adolescents who met the inclusion criteria were selected; the adolescents and their parents gave the written informed consent to participate in the study.

Data were collected through two in-depth interviews to each participant. The first interview was conducted after the dialysis with the hemodialysis adolescents and after the physician visit with the peritoneal dialysis adolescents. The second interview took place at the adolescents' home. Guidelines previously developed by the researchers were used for the interviews; however, the researcher always allowed the adolescents to freely express their thoughts and feelings. The interviews were done and transcribed by one of the researchers.

The data were initially analyzed during its collection to identify those issues the researchers felt needing clarification or more data. After collecting all data, an in-depthanalysis was done of theinterview transcriptions. In doing this, each adolescent's story was written and each interview transcription was read and interpreted in different moments. This analysis and interpretation allowed theidentification of similarities and differences in the participants' stories, which let to the identification of the themes that comprise the meaning of the dialysis catheter for the adolescents.

Ethics. The study was approved by the Human Ethics Committee of the Health Faculty of Universidad del Valle. Both parents and the adolescent gave the written informed consent to participate in the study.

\section{FINDINGS}

The teenagers had to learn to live with the consequences of having the catheter in their body. The catheter damaged the adolescents' physical appearance and peers relationships; it also was an obstacle to attain their identity. The following are the themes that comprise the catheter meaning for the adolescents; the adolescents' names used in describing the results are fictitious.

The catheter: something awful but necessary. The catheter size had the greatest impact on the adolescents. The adolescents did not have any idea about the catheter dimensions; they thought the dialysis catheter was like the peripheral IV catheters they were familiar with. Due to the lack of information about the catheter size, the 
adolescents had a picture of the catheter very different from the real one.

When they were going to put it on me ... they told me «we're going to put on a catheter» and then I said «O.K» because I thought it was a tiny thing like the ones they put on the vein when one is the hospital. So when they already put it on me and I woke up from the anesthesia then I quickly touched it to know how it was, and I touched my self and felt those long hoses, then I thought that wasn't the catheter and I asked my mom who was there with me and she said it was the catheter. So I felt a very strange thing and I told her «and with this I had to go home with?»

After the catheter was inserted in the adolescent's body, the adolescents explore it carefully to learn about the shape, the size and the place where it was laying. The adolescents felt the catheter was something grotesque in their body, especially those who got the hemodialysis catheter. This catheter is set in the right jugular vein and because of this it is more visible than the peritoneal dialysis catheter, which is set in the abdomen left flank. The adolescents having hemodialysis spent lots of time in front of the mirror looking at the catheter; by doing that, they realized the dressing and the tape holding and protecting the catheter magnified its size and presence for them and for everybody else.

At the beginning of the process to accept the catheter presence in their body, the adolescents felt great shame and sadness due to the fact they had to face the difficult task of adapting to the catheter as an element not belonging to their body but essential for the illness treatment, in other words they must learn to accept it as a part of their body.

I was very depressed when they put on me that catheter, the first I did... I didn't go out, I stayed in my room crying, I didn't want to leave my room, I cried, cried all the time. And my mom got desperate, my dad, my sisters told me «let's go out for a moment» and I said no, no; leave me alone here in my room, I felt very sad... and I was ashamed of that catheter.

After inspecting and acknowledging the catheter as something they should live with, the youngsters realized they had to go out to deal with the peers' reactions to the awful but indispensable catheter they had in their body. They created different ways to explain their peers why they had the catheter. Some felt this was a very hard situation and they considered they did not have to give any justification about the catheter; therefore they concealed the catheter under their clothes.

As soon as the adolescents got in contact with peers and other people, they had to deal with the questioning about the catheter: what was it? Why they had it? For how long would they have it? Besides the questioning, the adolescents had to handle their peers' continuous jokes. Even though, they had prepared themselves for this, they could not avoid feeling sad and anger. The questioning and jokes about the catheter did not decrease as time went by.

The adolescents' responses to others' reactions to the catheter were diverse; as a whole, they gave different explanations about the need for the catheter and avoid contact with peers and others whenever they could. Some such as Claudia only said she had it because of a health condition. Natalia gave lots of reasons but she was emphatic that was a transitory situation. Fernando felt the relationships with his peers from school deteriorated to the point he could not stand anymore life at school. He was quite unhappy at the beginning but soon the unhappiness became rage followed by being rude and physically aggressive with his peers.

The catheter as an obstacle for relating to peers. It is important to understand that for amusement the adolescents requires being with peers. So to lose the possibility of having fun as they were used to before the illness was one of the most difficult aspects they had to cope with; this was a significant loss for them. Losing this possibility was due basically to the restrictions imposed by the catheter. They must protect the catheter from getting wet, so they could not go swimming in rivers or swimming pools. They could not practice any exercises, play active games or dance because they must avoid excessive sweating since this damage the catheter dressing. Besides, they could not make any abrupt body movements to prevent displacement of the catheter by breaking the sutures holding the catheter. This situation generated feelings of nullity, sadness and anguish in the male adolescents.

The dialysis type did not make a difference in amusement restrictions for the youngsters. At first, they did not think of these restrictions as a loss; they even felt happy because they did not have to go to the physical exercises classes; while their classmates were in the exercises class, they could do others activities according to their preferences such as going to the cafeteria, the 
library, and the computer room. As time went by, this situation which seemed an advantage for the youngsters became a condition that made them feel sad, different, handicapped and pointed out by their peers. Peers completely excluded them from all the amusement projects.

The amusement situation outside of school was worse because their neighborhood friends and relatives also precluded them from their recreational activities as soon as they learned their health condition and the restrictions they had due to the catheter. Being excluded from the peer groups was something overwhelming for the teenagers; they felt they had a double loss: their friends and the opportunity to enjoy life. Because of this, feelings of frustration, sadness and nullity became stronger. They felt trapped in the vicious circle of «you can't, you can't, and you can». The adolescents having peritoneal dialysis could not go out at night so they could not be part of the peer meetings in the neighborhood in the evenings as it happens with David, Fernando and Esteban, who could not go to their friends' parties they were used to. Gathering at night with their peers from the vicinity was a significant activity for the adolescents, so they felt they were loosing their identity because they could not participate in these meetings.

The youngsters reacted in different ways to the loss of the entertainment with peers. Patricia learned to endure her friends and classmates' rejection and mocking; regardless Patricia's insistence, her peers and friends did not allow her to share their leisure time and activities. As a way to overcome this, Patricia asked for help to the adults around her. At school, she talked with the principal and teachers, who explained to Patricia's classmates her health condition and its consequences in Patricia's physical appearance. After these explanations, Patricia's classmates showed some compassion for her, some of them welcomed her in their group and allowed her to participate in the activities she was able to do but only for a short period. Outside of school, with her mother's help she was able to get her friends' acceptance. David looked for his family protection as a way to defend himself from his peer's rejection and the loss of amusement with them. This situation was identified by the health team in charged of his care as something morbid, so David and his mother were sent to psychotherapy. Being with the family was a source of tranquility and a means to relieve the sorrow David felt for not having contact and entertainment with his peers. David's family recreational activities were too boring for him; he was aware of his family's efforts to please his recreation needs but this did not preclude him for feeling sad, different, and alone; he yearned for having fun with his peers. Esteban reacted with behaviors that could be considered as self-destructive; he continued with all the recreational activities he was used to before the illness such as swimming in rivers and pools, playing hard games with his peers from school and neighborhood; he did not comply with the recommendations from the renal unit staff, he took good care letting his friends and peers know about his no compliance with the treatment. He did things that affect the placement and integrity of the catheter and his life such as injecting alcohol thru the catheter. As a result of these behaviors, Esteban had many fall backs and hospitalizations. Esteban was very disturbed by his friends' pity; anytime they showed some concern for his health; he became verbally and physically aggressive with them.

Fernando's choice was to abandon the school while he had the catheter. He was very careful in following the staff's instructions, especially those about the catheter. He almost completely discarded all of the recreational activities, even playing soccer which was his favorite sport. Fernando was very conscious he could not play soccer for a long time or maybe for ever. Regardless of his commitment to comply with the treatment, Fernando was hurt by the social isolation from his neighborhood friends; he did not understand why not playing soccer was an impediment for his friends to talk and spend some time with him; he felt sad because of that but he hoped the situation would change after he had the kidney transplant.

To cope with the loss of everyday recreation they were used to, the other adolescents from the study reduce the dialysis time, missed some of the visits to the clinic, and ate some «forbidden» foods in order to keep their previous status within their peers and beable to participate in the recreational activities. However, they were careful, never forgot their limitations but always felt different and handicapped.

Overall, all teenagers perceived the catheter as bothersome, as a hindrance, as something very awful, in other words as the main obstacle to do all the recreational activities they were used to before the illness. They understood the catheter was the main reason for having 
all the restrictions they had to live everyday, not the illness as such.

The catheter as an obstacle to be as somebody else. Clothing is important for all human beings but it is crucial for teenagers. The adolescents spend great part of their everyday life in trying to dress as other adolescents and show great concern for their outfits ${ }^{17}$. Clothing is a source of identity for the adolescents and allows them to show important aspects of their personality. Therefore, being fashion is quite important and becomes a requirement for them.

For the teenagers in dialysis, the dress was a cause of great stress because they had to adapt their clothes to having the catheter and the changes in body weight they were going thru. Girls did not wear the pants with low waist and the short tighten blouses that were in fashion. Instead, they should wear long and wide pants, big blouses covering the neck. For the boys, dressing was not as hard as for the girls since they could wear sport clothing, shirts and T-shirts covering their neck.

Teenagers felt the changes in the way they dressed were another important loss that cause them sadness, rage, frustration and mostly embarrassment. To be out of fashion or not dressing according to their preferences stripped of, in some way, their identity as adolescents.

Oh!!! Noo, Oh!!! Noo, this stresses me so much, yes because Oh!!! Noo, because when one sees the other girls in the neighborhood or in school wearing all those clothes one can't that is awful, one gets bored seeing the girls, the girls so pretty and one so ugly, and that should wear nothing, so I feel bad, I get furious, sometimes I feel like doing many things, it's that one looks like an old person.

There were differences in the way teenagers react to the loss of dressing like others, especially among the girls. Patricia could not wear the clothes she considered appropriated for her because the fluctuations in body weight, the multiple scars in her body, and the catheter. She felt rage and jealousy for not being able to look like her two older sisters, her classmates, and other women friends. Natalia, who most of the time was in peritoneal dialysis and with severe ascitis, was forced to wear very loose clothes. She was very ashamed, sad, anxious and felt quite different. It is important to mention Patricia and Natalia lived in a city with high temperatures most of the year where women dress clothes that expose their bodies.
Being unable of dressing the fashion clothing was also a loss for Claudia. However, it was not a significant loss for her because she adapted her clothing to the dialysis type and weight changes. Luisa did not feel bothered by the clothes she should wear. She had a congenital kidney disease with deformity of the legs and difficulties in walking so Luisa found the clothing she should wear more comfortable for her that the clothing she wore before the catheter.

For the boys, dressing was not a main concern, however they felt sad, embarrassed whenever they were around the girls, unselfconfident, different and sometimes point out by others; every so often peers made fun of them. The boys in peritoneal dialysis found the new way of dressing concealed better the increase in body weight. The boys avoided being with peers and used the dialysis procedure in the evenings as a plausible excuse for not going out with peers and friends.

The teenager boys in hemodialysis also had to change their way of dressing to sport clothes and loose T-shirt. During the first days of hemodialysis they followed the staff recommendation about wearing high neck T-shirts because they realized it was an excellent way to hide the catheter. After being in dialysis about six months, the boys did not continue wearing those T-shirt because of the heat and the sweat which bother them and might damage the catheter. Boys were conscious the questioning about the catheter would increase with the visible catheter.

Regardless it was easier for boys to mingle and go unnoticed by others, they perceived their outfits move them away from being a normal teenager so they felt rage, frustration, and shame.

All study participants, after one year of dialysis, began changing their dressing in order to look more like other adolescents.

\section{DISCUSSION, CONCLUSIONS, AND RECOMMENDATIONS}

The study findings show that for the adolescents, being in dialysis for a kidney chronicillness entails many efforts in learning to live with all changes and losses due to the dialysis catheter. This hard work and daily struggles of the adolescents are unknown for nurses and other health professionals, who because of this lack of knowledge might be too faraway from providing care based on the adolescent's needs. Consequently, the 
study results have implications for the care, specially nursing care, of the teenagers in dialysis.

The dialysis catheter was perceived by the study teenagers as something repulsive to see and touch but necessary to live until they had the kidney transplant. This finding suggests physicians and nurses caring for the adolescents in dialysis should regard as very important the placement, fixing and covering of the catheter, specially the hemodialysis catheter. Voluminous dressings and excessive taping that make the catheter more noticeable should be avoided to help teenagers to adapt or tolerate better the catheter. Due to the need of being especial and unique, adolescents are egocentric; this makes them to think whatever exists and concerns them, also exists and concerns everybody else. As a result of this egocentrism, adolescents feel others pay much attention to their physical appearance and behavior.

Teenagers also perceived the catheter as an obstacle for being like their peers and interacting with them. This means the catheter is lived as a barrier to achieve one of the adolescence most important developmental tasks: the development of a self- differentiated identity.

Nurses and psychologists play an important role in helping the adolescent to live with the dialysis catheter. Listening and providing information to the adolescents are means of helping them to live everyday with the catheter. Information should not be the traditional one but focused on their fears, concerns, doubts and regarding helpful coping strategies. The adolescents should be allowed to express what they are going thru in everyday life, how was his life before the illness and how it is with the illness. For the adolescents could be worthwhile to feel the health professionals in charge of their care attempt to understand the catheter impact on their lives, this could help them since they do not feel alone in their coping with the illness situation.

Health professionals also could help the adolescents thru facilitating meetings with other adolescents living similar health conditions who are coping successfully with the catheter and the illness. Interacting with peers in similar circumstances might strengthen the adolescent's identity and coping. Support groups also give the adolescents the opportunity to share with peers fears and effective coping strategies.

It is important health professionals stimulate adolescents to find amusement activities with peers going to the support group meetings. By doing this, the friendship ties, identity, and self-esteem are strengthened. Health professionals should make efforts to ensure lasting of the support groups such as finding a special meeting place, scheduling the meetings, and solving any meeting difficulties that could happen.

Interest conflict. The authors declare that there are no interest conflicts in this manuscript.

\section{ACKNOWLEDGEMENTS}

First of all, we thank the teenagers participating in the study for sharing their lived experiences with us despite all the daily demands and challenges they must face to live with the illness. Also we want to thank the adolescents' fathers and mothers and the staff from the renal unit where the adolescents were seen for facilitating the interaction between the adolescents and the researcher who did the adolescents' interviews.

\section{REFERENCES}

1. Sawyer SM, Bowes G. Adolescence on the health agenda. Lancet. 1999; 354 (Suppl II): 31-4.

2. Snethen JA, Broome ME, Barterls J, Warady BA. Adolescents'perception of living with end stage renal disease. Ped Nurs. 2001; 27: 159-66.

3. Gobierno de Chile, Ministerio de Salud. Guía Clínica Insuficiencia Renal Cronica Terminal. Ed. Santiago: Minsal, 2005. [citado 22 julio 2009]; [40 páginas]. Disponible en: www.redsalud.gov.cl/archivos/guiasges/INsuficiencia Renal.pdf

4. Gastelbondo AR, Cano Guzmán AM. Guía de manejo conservador en niños con insuficiencia Rrenal crónica. Rev Colomb Pediatr [revista en línea] 1998 [citado mayo 22 2007]; 33: [6 pantallas]. Disponible en: http://encolombia.com/medicina/ pediatria/pediatria35400etiologia5.htm

5. Otero LM. Enfermedad renal crónica. Colomb Med [revista en línea] 2002 [citado mayo 22 2007]; 33 (1): [6 pantallas]. Disponible en URL: http: // www.colombiamedica.univalle. edu.co/Vol33No1/renal.pdf

6. Martínez SJ. Identificación de variables asociadas a depresión y autoconcepto en pacientes con insuficiencia renal crónica atendidos en Fressenius Medical Care-Horizonte de la ciudad de Bogotá. Bogotá, DC: Pontificia Universidad Javeriana; 2002.

7. Fux CA, Uehlinger D, Bodmer T, Droz S, Zellweger C, Mühlemann K. Dynamics of hemodialysis catheter colonization by coagulase-negative staphylococci. Infect Control Hosp Epidemiol. 2005; 26: 567-74.

8. Moya-Mejía C, Fernández-Ros M, Ibeas-López J, AlcarazBusqueta J, Mañé-Buixó N, Yuste-Jiménez E, et al. Monitorización sistemática del catéter permanente: una he- 


\section{Colombia Médica}

rramienta útil en el estudio de la tasa de infección y disfunción en dos tipos de catéteres tunelizados para hemodiálisis. Rev Soc Esp Enferm Nefrol. 2006, 9: 165-71.

9. Leaños-Miranda A, Garduño-Espinosa J, Martínez-García M del C. Factores asociados a falla del catéter de diálisis peritoneal en insuficiencia renal crónica Rev Invest Clin. 1997; 49: 189-95.

10. Guzmán Valdivia-Gómez G, Jaramillo de la Torre E. Abordaje por línea media o paramedia en la colocación de catéter de Tenckhoff en pacientes con diálisis peritoneal continua ambulatoria. Estudio comparativo. Cir Ciruj. 2004; 72: 193201.

11. Blessing WD, Ross JM, Kennedy CI, Richardson W. Laparoscopic-assisted peritoneal dialysis catheter placement: an improvement on the single trocar technique. Am Surg. 2005; 71: 1042-6.

12. Crabtree JH, Fishman A. A laparoscopic method for optimal peritoneal dialysis access. Am Surg. 2005; 71: 135-43.

13. Mathew L, Surendranath C, Saad T, Half G, Esterl R. A new salvage procedure for peritoneal dialysis catheters with exit
Vol. 40 N 3, 2009 (Julio-Septiembre)

site infections. Am Surg.1998; 64: 1215-7.

14. Pérez-Delgado J, Sotolongo-Molina Y, Muradás-Augier M, Vigoa-Sánchez L, Lugo-López E. Supervivencia y complicaciones de los catéteres para hemodiálisis: nuestra experiencia. Rev Cubana Cirug. [revista on-line] 2006; [citado 22 julio 2009]; 45: [8 páginas]. Disponible en: http://scielo.sld.cu/ pdf/cir/v45n3-4/cir08306.pdf

15. Castillo-Espitia E. La fenomenología interpretativa como alternativa apropiada para estudiar los fenómenos humanos. Inv Educ Enf. [revista en línea] 2000 marzo [citado mayo 22 2007]; 18 (1): [21 pantallas]. Disponible en URL: http:// www.udea.edu.co/revista

16. Benner P. The tradition and skill of interpretive phenomenology in studying health, illness, and caring practices. En: Benner, P(ed.). Interpretive phenomenology: embodiment, caring, and ethics in health and illness. Thousand Oaks: Sage; 1994. p. 112-8.

17. Vásquez ML. Significado da regulação da fecundidade para os/as adolescentes numa comunidade urbana marginal. [Teses em enfermagen]. Florianápolis: Editora da UFSC; 2001. 